\title{
Studies on a Fibrinolytic Enzyme from Bacillus species
}

\author{
Rajani Gopal Gad ${ }^{1 *}$, S. Nirmala ${ }^{2}$ and S. Narendar Sivvaswamy ${ }^{3}$ \\ 'Department of Bioinformatics, Faculty of Science and Humanities, SRM University, \\ Kattankulathur, Chengalpattu 603 203, India; sukruti226@gmail.com \\ 2Department of Biochemistry, SRM Dental College, Ramapuram, Chennai 600 089, \\ India; dr_s_nirmala@yahoo.com \\ 3SynkroMax Biotech Pvt Ltd, 118 First Floor, Kundrathur Main Road, M S Nagar, Porur, \\ Chennai 600 116, India; nsivaswamy@gmail.com
}

\begin{abstract}
Two species of Bacillus, namely, Bacillus amyloliquefaciens and Bacillus licheniformis, isolated from spoilt milk and soy flour, respectively, exhibited fibrinolytic enzyme (Nattokinase) activity. In the laboratory scale studies, of these two cultures, B. amyloliquefaciens produced the Fibrinolytic enzyme in higher quantities, $28.98 \mathrm{FU} / \mathrm{mL}$, compared to 26.63 $\mathrm{FU} / \mathrm{mL}$ in B. licheniformis. The maximal activities were obtained after $72 \mathrm{~h}$. The optimum conditions at laboratory for maximal production of the fibrinolytic (Nattokinase) enzyme were: $\mathrm{pH} 7.2$, temperature $37 \mathrm{C}$ and agitation $200 \mathrm{rpm}$. In scale up trials in a $7 \mathrm{~L}$ fermentor, the fibrinolytic activity of B. amyloliquefaciens was 55.6 at $72 \mathrm{~h}$. The molecular weight of the enzyme was estimated to be about $38 \mathrm{kDa}$. The enzyme had exhibited excellent blood clot dissolving property and therefore may be considered for further scale up and commercial exploitation.
\end{abstract}

Keywords: Bacillus amyloliquefaciens, Bacillus licheniformis, Commercial Prospects, Fibrinolytic Enzyme, Nattokinase

\section{Introduction}

Thrombolytic agents are used to treat heart attack, stroke, deep vein thrombosis, pulmonary embolism and occlusion of a peripheral artery or in dwelling catheter ${ }^{1}$. All thrombolytic agents are serine proteases and convert plasminogen to plasmin (EC 3.4.21.7), which breaks down the fibrinogen and fibrin and dissolves the clot. Currently available thrombolytic agents include reteplase (r-PA or Retavase), alteplase (t-PA or Activase), urokinase (Abbokinase), prourokinase, Anisoylated Purified Streptokinase Activator Complex (APSAC) and streptokinase ${ }^{2}$. These activators are of human origin, which are generally safe, but are very expensive. Therefore, fibrinolytic enzymes of microbial origin are of great importance and have wide range of applications in pharmaceutical industry, healthcare and medicine. The mechanism of Fibrinolytic Enzyme (Nattokinase) enzyme was reported to possess not only the plasminogen activator activity but also to directly digest fibrin by limited proteolysis.

Bacillus species produce a variety of extracellular and intracellular proteases, such as proteases, neutral metalloprotease, esterase and serine proteases ${ }^{3}$. Fibrinolytic Enzyme (Nattokinase), a serine protease, was for the first time isolated from Bacillus subtilis var natto by Sumi ${ }^{4}$. It is considered as a potent cardiovascular drug. Fibrinolytic Enzyme (Nattokinase) is one of the most powerful new dietary supplements introduced in the market in recent years. Fibrinolytic Enzyme

${ }^{*}$ Author for correspondence 
(Nattokinase) enhances the body's ability to dissolve blood clots in several ways. Not only it is able to potently decompose fibrin directly, but it also enhances the body's production of both plasmin and other clot dissolving agents including (endogenous) prourokinase. As fibrin is being dissolved, levels of EFA (Euglobin Fibrinolytic Activity) and FDP (Fibrin Degradation Products) increase in the blood. The increase in these parameters allowed researchers to confirm the action of Fibrinolytic Enzyme (Nattokinase) and also determine that the activity lasts from eight to twelve hours. Fibrinolytic Enzyme (Nattokinase) is truly a multidimensional nutrient supplement and can play a key role in treating hypertension and hypercoagulation. Compared with conventional clot dissolving drugs, Fibrinolytic Enzyme (Nattokinase) has several advantages, such as: Oral administration, Safety, Convenience, Confirmed efficacy, Preventive effect, Prolonged effects and Low cost and stability in gastrointestinal tract. Therefore, the fibrinolytic (Nattokinase) enzymes from Bacillus species have attracted much interest among the researchers worldwide because of their promising effects in the study of thrombolytic process including the activation of plasmin. This study was undertaken to screen for microorganisms producing fibrinolytic (Nattokinase) enzyme, particularly from Bacillus species, from different sources and to study its potential for commercial application.

\section{Materials and Methods}

\subsection{Objectives}

The major objective of this research work was to isolate and screen microorganisms for the production of fibrinolytic enzyme (Nattokinase). The shortlisted cultures would be identified through biochemical and molecular tests. Further it was proposed to optimise the cultural conditions to improve the enzyme activity. The ultimate objective was to scale up the process to achieve the maximal activity and to study the possibilities of commercial application of this fibrinolytic enzyme (Nattokinase).

\subsection{Experimental Work}

\subsubsection{Isolation and Screening of Microorganisms}

Samples of Soya flour, Soil from an abattoir, Spoilt milk, Rinds of Water Melon, Soybean and Shouyu (a
Japanese soybean sauce) were tried for the isolation of microorganisms. Bacteria and fungi, which were isolated from the above samples, were later subjected to Casein Hydrolysis Plate Assay method ${ }^{5}$. Twelve bacterial cultures, which exhibited clear zone in the plates (proteolytic activity), were selected for further studies.

\subsubsection{Screening for Proteolytic Activity}

Preliminary screening was carried out by evaluating the fibrinolytic enzyme producing capacity of the microorganisms. These bacterial cultures were grown in a minimal medium containing Glucose $1.0 \%$, Peptone $3.0 \%, \mathrm{MgSO}_{4}$ $0.20 \%$ and $\mathrm{CaCl}_{2} 0.50 \%, \mathrm{pH}$ adjusted to 7.0 , at $37 \mathrm{C}$ at 200 $\mathrm{rpm}^{6}$. After $48 \mathrm{~h}$ of growth, the biomass was separated by centrifugation $(10,000 \mathrm{rpm}, 15 \mathrm{~min}, 4 \mathrm{C})$ and the clear supernatant was taken for fibrinolytic enzyme assay ${ }^{7}$. The crude enzyme (culture filtrate) preparations were also tested for their blood clot dissolving property. The cultures were also grown on blood plates to observe the clear zone.

\subsubsection{Biochemical and Molecular Characterisation of Selected Cultures}

Two bacterial cultures, which were shortlisted based on the above screening procedures, were subjected to Gram Staining and observed under microscope. In order to identify the cultures, the following biochemical tests were carried out ${ }^{8}$ :

(1) Indole Test, (1) Methyl Red Test, (3) Voges Proskaeur Test, (4) Citrate Utilisation Test, (5) Triple Sugar Iron Agar Test, (6) Catalase Test, (7) Oxidase Test (8) Sugar Fermentation Test, (9) MacConkey's Agar Test, (10) Motility Test and (11) Urease Test. Genomic DNA was isolated from these two cultures and quantified. Identification of the cultures was done by amplification of $16 \mathrm{~S}$ rRNA analysis8.

\subsubsection{Optimization Studies}

For the optimal production of fibrinolytic (Nattokinase) enzyme, various media were tried (Table 1). Effect of different nitrogen and carbon sources were studied. The culture filtrates were periodically assayed for fibrinolytic activity $^{7}$ and total protein content ${ }^{9}$.

The optimum $\mathrm{pH}$ for the enzyme activity was studied by varying the $\mathrm{pH}$ levels, from 4.0 to 9.0. Similarly, the optimum temperature for the enzyme activity was 
Table 1. Different production media used for proteolytic enzyme production

\begin{tabular}{|c|c|c|c|c|c|}
\hline PRODUCTION MEDIA & $\begin{array}{l}\text { GLUCOSE } \\
\left(\text { GLU) }(\%)^{6}\right.\end{array}$ & $\begin{array}{c}\text { YEAST } \\
\text { EXTRACT } \\
(\mathrm{YE})(\%)^{22}\end{array}$ & $\begin{array}{c}\text { GLUCOSE+ } \\
\text { SOYBEAN MEAL } \\
(\mathrm{G}+\mathrm{S})(\%)^{23}\end{array}$ & $\begin{array}{c}\text { MALTOSE+ } \\
\text { WHEAT BRAN } \\
(\mathrm{M}+\mathrm{B})(\%)^{23}\end{array}$ & $\begin{array}{c}\text { GREENGRAM } \\
\text { DHAL (GGD) } \\
(\%) \\
\end{array}$ \\
\hline GLUCOSE & 1.0 & 1.0 & 2.0 & & \\
\hline PEPTONE & 5.5 & & & & \\
\hline $\mathrm{MgSO}_{4} \cdot 7 \mathrm{H}_{2} \mathrm{O}$ & 0.2 & & & & \\
\hline $\mathrm{CaCl}_{2}$ & 0.5 & & & & \\
\hline YEAST EXTRACT & & 1.0 & & & \\
\hline $\mathrm{K}_{2} \mathrm{HPO}_{4} \cdot 3 \mathrm{H}_{2} \mathrm{O}$ & & 0.01 & 0.4 & 0.4 & \\
\hline $\mathrm{MgSO}_{4} \cdot 7 \mathrm{H}_{2} \mathrm{O}$ & & 0.05 & 0.05 & 0.05 & \\
\hline SOYBEAN MEAL & & & 2.0 & & \\
\hline $\mathrm{NaCl}$ & & & 0.5 & 0.5 & \\
\hline $\mathrm{KH}_{2} \mathrm{PO}_{4} \cdot 3 \mathrm{H}_{2} \mathrm{O}$ & & & 0.1 & 0.1 & \\
\hline MALTOSE & & & & 2.0 & \\
\hline WHEAT BRAN & & & & 3.0 & \\
\hline GREEN GRAM DHAL & & & & & 10.0 \\
\hline SUGAR & & & & & 4.0 \\
\hline $\mathrm{CaCO}_{3}$ & & & & & 1.0 \\
\hline $\mathrm{NaH}_{2} \mathrm{PO}_{4}$ & & & & & 0.06 \\
\hline $\mathrm{Na}_{2} \mathrm{HPO}_{4}$ & & & & & 0.056 \\
\hline ANTIFOAMER & & & & & 0.1 \\
\hline
\end{tabular}

estimated by studying the enzyme activity at different temperatures, from $30-70^{\circ} \mathrm{C}$.

\subsubsection{Partial Purification of Fibrinolytic (Nattokinase) Enzyme}

Ammonium sulphate precipitation method was followed for the partial purification of the enzyme. The procedure was tried with $20 \%, 30 \%, 40 \%, 50 \%, 60 \%, 70 \%$ and $80 \%$ of ammonium sulphate for both the culture filtrates. Dialysis was done extensively until the protein concentrate was obtained and the protein concentrate was subjected to SDS-PAGE Electrophoresis ${ }^{10}$.

\subsubsection{Scale Up Studies}

Scale up studies were carried out in a laboratory $7 \mathrm{~L}$ Fermentor (Scigenics, India). The composition of Seed Medium (\%) was: Glucose 2.0, Soybean meal 2.0, Sodium chloride $0.5, \mathrm{KH}_{2} \mathrm{PO}_{4} 0.1, \mathrm{~K}_{2} \mathrm{HPO}_{4} 0.4$, Magnesium sulphate 0.05 and $\mathrm{pH}$ 7.2. The Production Medium (\%) contained: Wheat bran 3.0, Maltose 2.0, Sodium chloride 0.5, $\mathrm{KH}_{2} \mathrm{PO}_{4} 0.1, \mathrm{~K}_{2} \mathrm{HPO}_{4}$ 0.4, Magnesium sulphate 0.05 and $\mathrm{pH} 7.2$.

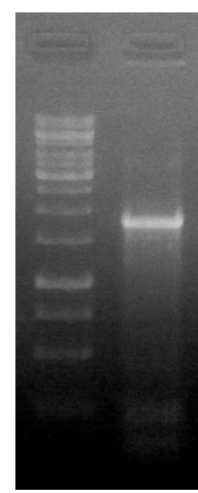

Figure 1. Amplification of fibrinolytic serine protease gene.

\subsubsection{Amplification of Serine Protease Gene}

Genomic DNA from B. amyloliquefaciens was amplified by the method of Saito et $\mathrm{al}^{11}$. The primer used was (P1, 5_-TCACAGCTTTTCTCGGTC-3_; P2, 5_ -TGATCCGATTACGAATGC-3_). Amplification was carried out in a gradient PCR unit (Figure 1): 1 cycle at $94^{\circ} \mathrm{C}$ for $3 \mathrm{~min}, 20$ cycles of denaturation at $94^{\circ} \mathrm{C}$ for 1 min, annealing to $42 \mathrm{C}$ for $1 \mathrm{~min}$ and extension at $72^{\circ} \mathrm{C}$ for $2.5 \mathrm{~min}$ and additional extension at $72^{\circ} \mathrm{C}$ for $10 \mathrm{~min}$. 
Lane 1: 1Kb Ladder (10,000 bp, 8000 bp, 6000 bp, 5000 bp, 4000 bp, 3000 bp, 2500 bp, 2000 bp, 1500 bp, 1000 bp, 750 bp, 500 bp, 250 bp)

Lane 2: PCR Amplicon of fibrinolytic serine protease gene (MB)

\section{SEQUENCE ANALYSIS of B. amyloliquefaciens}

>054-1212_153_001_RAN_FSP-F-F08.ab1

CAAGAGAGCGATCGCGGCTGTGTACAAATACTCATGTCCTTCCATCGGTTTTTTCCATTA AAATTTAAATATTTCGGGTTCCTATTAAACGAAAGAGAGATGATATACCTAAATAGAAAT AAAACAAACTGAAAAAAATTGGGTCTACTAAAATATTATTCCATGCTATACAATTAATCC ACAGAATAATCTGTCTATTGGTTGTTCTGCAAATGAAAAAAAGGAGAGGATAAAGAGTGA GAGGCAAAAAGGTATGGATCAGTTTGCTGTTTGCTTTAGCGTTAATCTTTACGATGGCGT TCGGCAGCACGTCTCCTGCCCAGGCGGCAGGGAAATCAAACGGGGAAAAGAAATACATTG TCGGATTTAAACAGACAATGAGCACGATGAGCGCCGCTAAGAAAAAAGATGTCATTTCTG AAAAAGGCGGGAAAGTGCAAAAGCAATTCAAATATGTAGACGCAGCTTCAGCTACATTAA ATGAAAAAGCCGTAAAAGAGCTGAAAAAAGACCCTAGCGTCGCTTACGTTGAAAGAAGAT CACGTTGCACAGGCGTACGCGCAGTCCGTGCCTTTACGGCGTATCACAGATTAAAGCCCC TGCTCTGCACTCTCAAGGCTTCACCGGATCAAATGTTAAAGTAGCGGTTATCGACAGCGG TATCGATTCTTCTCATCCTGGATTTAAGGGTAGCAGGCGGAGCCAGCATGGTTCCCTTCT GAAAACAAATCCTTTCCAAGAACAACACTCTCACGGAACTTCACGTTGCCGGTCAGTTGC CGCTTCTTAATTAACCTCAGTCGGTGTATTTAGGCGTTGCGCCAAGCGCATCTTCTTTAC GCTTGTAAAAGTTCTCGCGCCTGAACGGGTCGCCCATTACAGCTTGGAATCATATCGAAT

\subsubsection{Protein Structure Prediction}

The following sequence was subjected for modelling:

$>\operatorname{tr|E5LCP0|E5LCP0\_ BACAM~Fibrinolytic~enzyme~OS=Bacillus~amyloliquefaciens~} \mathrm{PE}=3 \mathrm{SV}=1$ MRGKKVWISLLFALALIFTMAFGSTSPAQAAGKSNGEKKYIVGFKQTMSTMSAAKKKDVI SEKGGKVQKQFKYVDAASATLNEKAVKELKKDPSVAYVEEDHVAQAYAQSVPYGVSQIKA PALHSQGFTGSNVKVAVIDSGIDSSHPDLKVAGGASMVPSETNPFQDNNSHGTHVAGTVA ALNNSVGVLGVAPSASLYAVKVLGADGSGQYSWIINGIEWAIANNMDVINMSLGGPSGSA ALKAAVDKAVASGVVVVAAAGNEGTSGGSSTVGYPGKYPSVIAVGAVNSSNQRASFSSVG SELDVMAPGVSIQSTLPGNKYGAYNGTSMASPHVAGAAALILSKHPNWTNTQVRSSLENT TTKLGDAFYYGKGLINVQAAAQ

As crystal structure of serine protease is unavailable 3-Dimensional structure was built using homology modelling. The protein sequence of Fibrinolytic Enzyme (Nattokinase) (Accession No. WP_017417394.1, length: 382 amino acid) was retrieved from NCBI GenBank. The template protein was identified using BLASTp tool. The crystallographic structure of 1SBN_E was downloaded from Protein Data Bank (PDB) and used as a template (resolution 2.10A). The template and the target sequences showed $97 \%$ identity and $71 \%$ similarity with query coverage of 503 total score and E value of $7 \mathrm{e}-179$. Thus, the sequence similarity between Target and 1 SBN_E is reasonable for selecting 1 SBN_E as a suitable template for modelling of our sequence (Figure 2). The initial model (Figure 3) was developed using Prime Module software. The bumps were removed and missing side chain atoms were added using the WHAT IF Web Interface (http://swift.cmbi.ru.nl/ servers/html/index. html). The prerefined model was examined through Ramachandran plot and the loop refinement was performed using Prime Module. The modelled structure was evaluated using PROCHECK server. The structural superimposition of 1 SBN_E chain A and target protein was performed using PyMOL molecular viewer (http:// www.pymol.org) and the structural alignment was done using Genious Pro. 


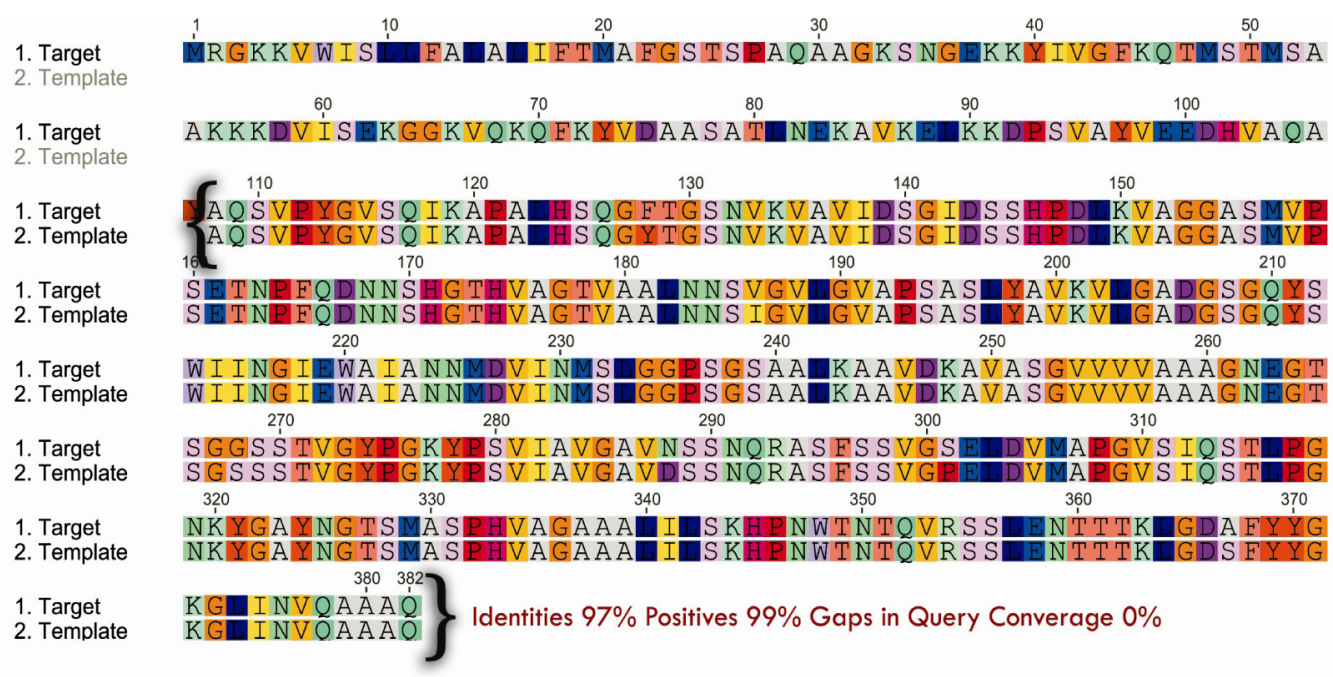

Figure 2. Alignment between template and target sequence.

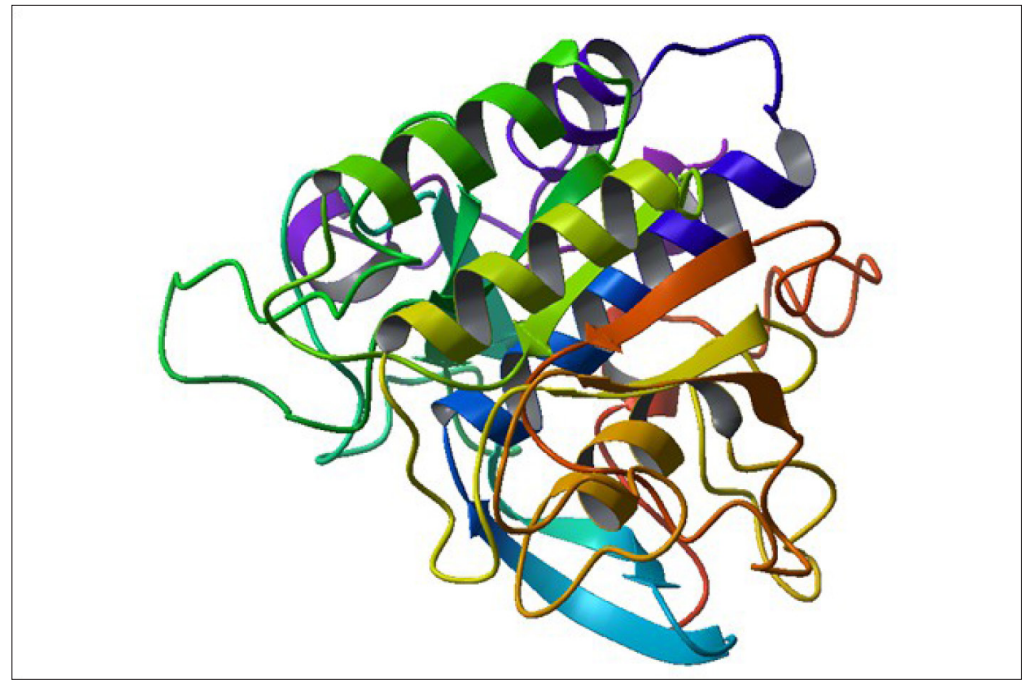

Figure 3. 3D structure of the modelled protein.

\section{Results and Discussion}

\subsection{Isolation and Screening of Microorganisms}

A total of seventy five microorganisms (40 bacteria and 35 fungi) were isolated from the above mentioned sources using serial dilution method. These microorganisms were subjected to casein hydrolysis plate assay and twelve bacterial cultures, which exhibited clear zone, were selected.

\subsection{Screening of Proteolytic Activity}

The shortlisted twelve microorganisms were grown in a minimal medium (LB Broth) and the enzyme activity was estimated in the culture filtrate. The results are presented in Table 2. It is clear from the results that two bacterial isolates, namely, MB and SF2, gave maximal protease activities. Incidentally, these two bacterial isolates exhibited bigger clear zones in the Casein Plate assay (Figure 4). These cultures were later subjected to blood clot dissolution and blood plate assays. Both the cultures exhibited very clear zones in the blood plate assay (Figure 5) and dissolved the blood clot (Figure 6).

\subsection{Biochemical and Molecular Characterisation}

The final shortlisted two bacterial cultures were identified as gram positive rods arranged in pairs or chains 


\begin{tabular}{lcc}
\multicolumn{2}{c}{ Table 2} & \multicolumn{2}{c}{ Proteolytic Enzyme activity } \\
\hline No & Culture & Enzyme Activity $(\mathrm{mg} / \mathrm{mL})$ \\
\hline 1 & SF1 & 1.45 \\
2 & SF2 & 5.76 \\
3 & SF3 & 1.24 \\
4 & MB & 6.70 \\
5 & MB1 & 2.41 \\
6 & MB2 & 1.36 \\
7 & SB1 & 2.19 \\
8 & SB2 & 3.21 \\
9 & SH1 & 4.01 \\
10 & SH2 & 2.90 \\
11 & WM1 & 1.45 \\
12 & WM2 & 3.67 \\
\hline
\end{tabular}

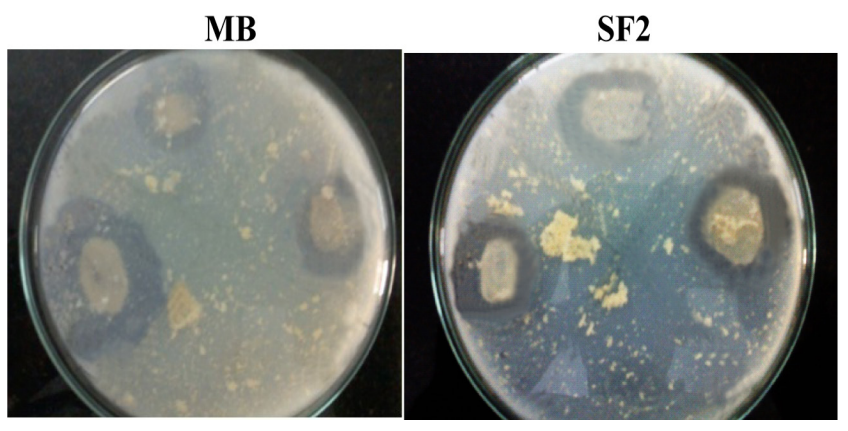

Figure 4. Casein plate assay.

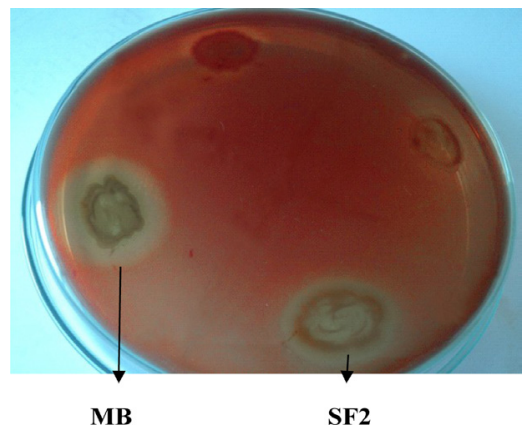

Figure 5. Blood plate assay.

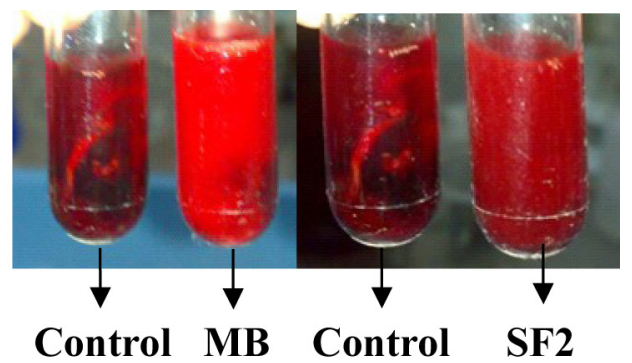

Figure 6. Blood clot dissolution assay. with single elliptical endospore, typical of Bacillus species $^{12,13}$. Bacillus species adhere to the culture medium and the spores resist temperature and insufficient nutrients. Based on the results obtained from the biochemical tests (Table 3), the cultures were confirmed as Bacillus species. The genomic DNA isolated from both the cultures (Figure 7 and 8) were amplified and 16S rRNA was sequenced. The sequence of the primers used was:

Bac 16s-F: 5' AGAGTTGATCATGGCTCAG 3' Bac 16s-R: 5' TACGGCTACCTTGTTACGACTT 3'

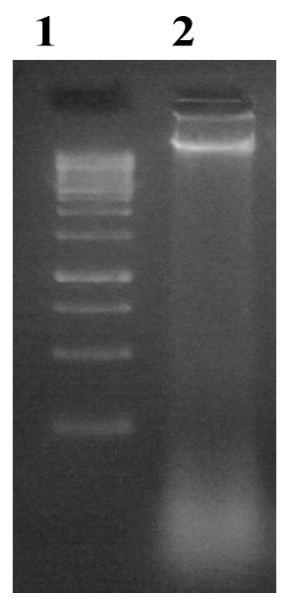

Figure 7. Genomic DNA Isolation (MB).

Lane 1: 1Kb Ladder (10,000 bp, 8000 bp, 6000 bp, 5000 bp, 4000 bp, 3000 bp, 2500 bp, 2000 bp, 1500 bp, 1000 bp, $750 \mathrm{bp}, 500 \mathrm{bp}, 250 \mathrm{bp}$

Lane 2: Genomic DNA (MB) Bacillus amyloliquefaciens

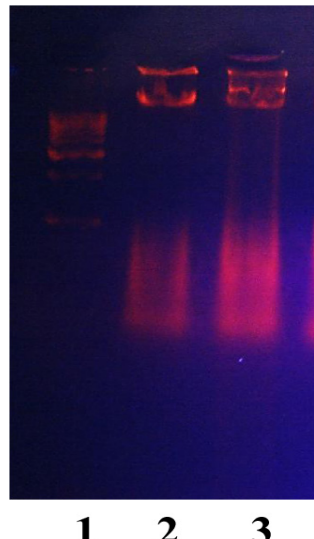

Figure 8. Genomic DNA isolation (SF2).

Lane 1: 1Kb Ladder (10,000 bp, 8000 bp, 6000 bp, 5000 bp, 4000 bp, 3000 bp, 2500 bp, 2000 bp, 1500 bp, 1000 bp, 750 bp, 500 bp, 250 bp)

Lanes 2 \& 3: Genomic DNA of (SF2) B. licheniformis 
Based on the sequencing, the bacterial culture (MB) was identified as Bacillus amyloliquefaciens (Figure 9) and SF2 was identified as Bacillus licheniformis (Figure 10). The sequences were registered with NCBI GenBank (B. amyloliquefaciens - KF186621.1; B. licheniformis KF186622.1).

Table 3. Biochemical tests

\begin{tabular}{|c|c|c|c|}
\hline No & Test & MB & SF2 \\
\hline 1 & Morphology & $\begin{array}{c}\text { Gram Positive } \\
\text { Rod }\end{array}$ & $\begin{array}{c}\text { Gram Positive } \\
\text { Rod }\end{array}$ \\
\hline 2 & Indole Test & - & - \\
\hline 3 & Methyl Red Test & - & - \\
\hline 4 & $\begin{array}{c}\text { Voges Prouskeur } \\
\text { Test }\end{array}$ & - & + \\
\hline 5 & Citrate Test & + & + \\
\hline 6 & $\begin{array}{c}\text { Triple Sugar Iron } \\
\text { Test }\end{array}$ & Slight Gas & Slight Gas \\
\hline 7 & Catalase Test & + & + \\
\hline 8 & Oxidase Test & + & + \\
\hline 9 & $\begin{array}{c}\text { Sugar } \\
\text { Fermentation Test }\end{array}$ & No Acid/Gas & No Acid/Gas \\
\hline 10 & $\begin{array}{c}\text { Mac Conkey's } \\
\text { Agar Test }\end{array}$ & - & - \\
\hline 11 & Motility Test & + & + \\
\hline 12 & Urease Test & - & - \\
\hline
\end{tabular}

\section{SEQUENCE}

$>$ V250_16S_F

ACGGAGATGGGGGGGCTTCCCTAAAAATTGCAAGTCGGAGCGGACAGATG GGAGCTTGCTCCCCTGATGTTAGCGGCGGACGGGTGAGTAACACGTGGGT AACCTGCCTGTAAGACTGGGATAACTCCGGGAAACCGGGGCTAATACCGG ATGGTTGTTTGAACCGCATGGTTCAGACATAAAAGGTGGCTTCGGCTACC ACTTACAGATGGACCCGCGGCGCATTAGCTAGTTGGTGAGGTAACGGCTC ACCAAGGCAACGATGCGTAGCCGACCTGAGAGGGTGATCGGCCACACTGG GACTGAGACACGGCCCATACTCCTACGGGAGGCACCGTAGGGAATCTTCC GCATTGGACGAAAGTCTGACGGAGCAACGCCGCGGGAGTGATGAAGGTTT TCGGATCGTAAAGCTCTGTTGTTAGGGAAAAACAAGTGCCGTTCAAATAG GGCGGCACCTTGACGGTACCTAACCAGAAAGCCACGGCTAATTACGTGCC GCAGCCGCGGTAATACGTAGGTGGCAATCGTTGTCCAGAAATTATTGGGC GTAAAAGGGCTCGCAGGCGGTTTCTTAATTCTGATGTGAAAAGCCCCCGG CTCAACCGGGGAGGGTCATTGGAAACTGGGGGAACTTGAGTGCAAAAAGG AGAGTGGAATTCCACGTGTATCGGTGAAATGCGTAAAATGTGGAGGAACA CCAGTGGCAAAGGCGATTCTCTGGTCTGTAACTGACGCTCAGGAGCGAAA TCGTGGGGAACGAACCGGATTAGATACCCTGGGTATCCCCCCCTAAACGA TGATTGCCCAGTGTTAGGGGGTTTCCCCCCCCTTATGCTGCCA 


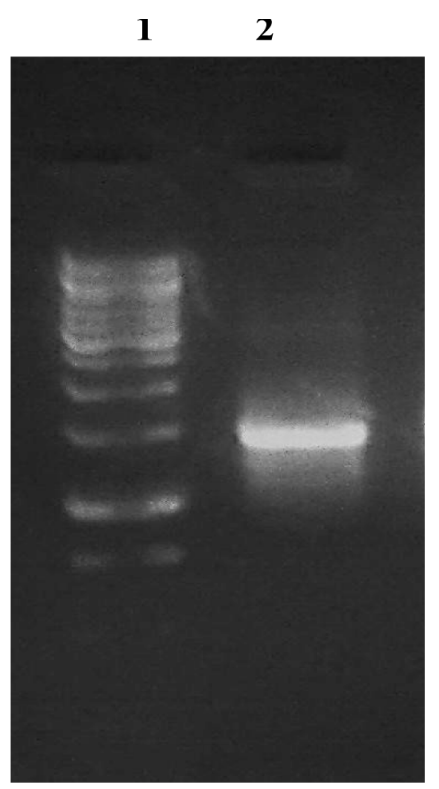

Figure 10. Amplification Of 16S rRNA (SF2).

Lane 1: 1Kb Ladder (10,000 bp, 8000 bp, 6000 bp, 5000 bp, 4000 bp, 3000 bp, 2500 bp, 2000 bp, 1500 bp, 1000 bp, 750 bp, $500 \mathrm{bp}, 250 \mathrm{bp}$ )

Lane 2: Amplified 16s rRNA from SF2

\section{SEQUENCE:}

>BRTPL_RG_16s

AGTCGAGCGGACAGATGGGAGCTTGCTCCCTGATGTTAGCGGCGGACGGGTGAGTAA CACGTGGGTAACCTGCCTGTAAGACTGGGATAACTCCGGGAAACCGGGGCTAATACCG GATGGTTGTTTGAACCGCATGGTTCAGACATAAAAGGTGGCTTCGGCTACCACTTACA GATGGACCCGCGGCGCATTAGCTAGTTGGTGAGGTAACGGCTCACCAAGGCAACGAT GCGTAGCCGACCTGAGAGGGTGATCGGCCACACTGGGACTGAGACACGGCCCAGACT CCTACGGGAGGCAGCAGTAGGGAATCTTCCGCAATGGACGAAAGTCTGACGGAGCAA CGCCGCGTGAGTGATGAAGGTTTTCGGATCGTAAAGCTCTGTTGTTAGGGAAGAACAA GTGCCGTTCAAATAGGGCGGCACCTTGACGGTACCTAACCAGAAAGCCACGGCTAACT ACGTGCCAGCAGCCGCGGTAATACGTAGGTGGCAAGCGTTGTCCGGAATTATTGGGCG TAAAGGGCTCGCAGGCGGTTTCTTAAGTCTGATGTGAAAGCCCCC

\subsection{Optimization Studies}

Several media were tried with different combinations of carbon and nitrogen sources in order to achieve high activities. Carbon sources, such as, maltose, mannitol, fructose, glucose, sucrose and lactose ${ }^{14}$ and nitrogen sources, such as, Casein, $\mathrm{NH}_{4} \mathrm{Cl}, \mathrm{KNO}_{3}, \mathrm{NH}_{3} \mathrm{PO}_{4}$ and soy peptone ${ }^{15}$ were tried. The medium which contained wheat bran and maltose gave maximal activities. After $72 \mathrm{~h}$ of growth, Bacillus amyloliquefaciens produced $30.2 \mathrm{U} / \mathrm{mL}$ (Figure 11) of proteolytic Enzyme and B. licheniformis produced $28.12 \mathrm{U} / \mathrm{mL}$ of proteolytic enzyme (Figure 12). When the same culture filtrate was evaluated for fibrinolytic activity using fibrin assay method, the activity was $28.98 \mathrm{FU} / \mathrm{mL}$ in B.amyloliquefaciens and 26.63 $\mathrm{FU} / \mathrm{mL}$ in B.licheniformis (Table 4). The optimum $\mathrm{pH}$, temperature and agitation for the maximal production were 7.2, $37 \mathrm{C}$ and $200 \mathrm{rpm}$, respectively. According to Al-Juamily and Al-Zaidy ${ }^{12}$, the optimal conditions for fibrinolytic enzyme production were determined, using a solid Lentils medium (activity $25.25 \mathrm{U} / \mathrm{mL}$ ) at $\mathrm{pH} 7.2$ $(65.381 \mathrm{U} / \mathrm{mL}), 48 \mathrm{~h}$ incubation time $(15.766 \mathrm{U} / \mathrm{mL})$ and shaking incubator $(95.992 \mathrm{U} / \mathrm{mL})$. The optimal carbon and nitrogen sources were mannitol and peptone or soya peptone with activity 44.0 and $50.0 \mathrm{U} / \mathrm{mL}$, respectively. 
Table 4. Fibrinolytic activity.

\begin{tabular}{lcc}
\hline DESCRIPTION & STATE & ACTIVITY ( FU/mL) \\
\hline $\begin{array}{l}\text { NATTOKINASE } \\
\text { (COMMERCIAL) }\end{array}$ & POWDER & $370(\mathrm{FU} / \mathrm{g})$ \\
$\begin{array}{l}\text { Fibrinolytic Enzyme } \\
\text { B.amyloliquefaciens }\end{array}$ & LIQUID & 28.98 \\
$\begin{array}{l}\text { Fibrinolytic Enzyme } \\
\text { B.licheniformis }\end{array}$ & LIQUID & 26.63 \\
\hline
\end{tabular}

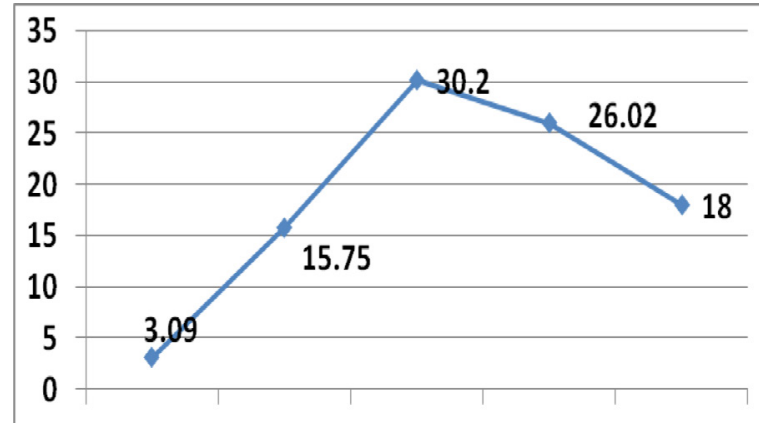

1ST Day 2ndDay 3rdDay 4th Day 5th Day

Figure 11. Proteolytic activity of B. amyloliquefaciens.

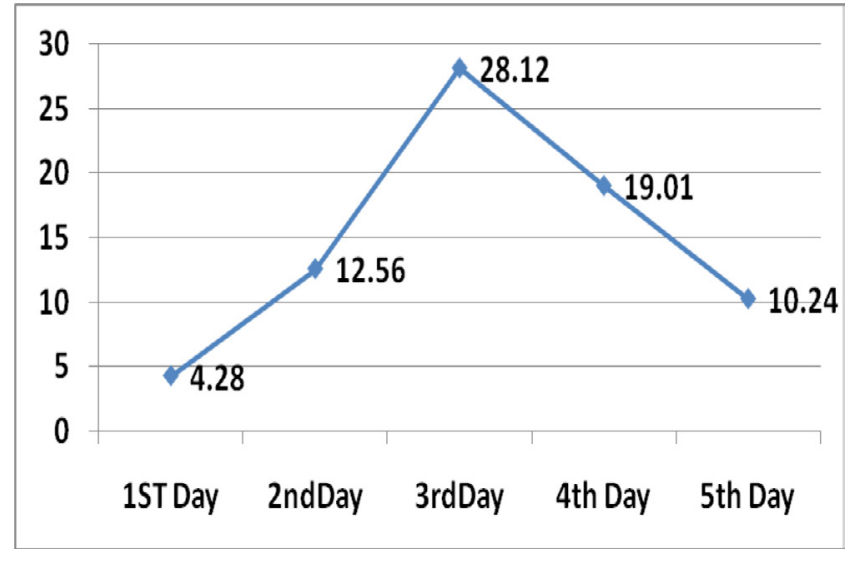

Figure 12. Proteolytic activity of B. licheniformis.

Wang et $\mathrm{al}^{5}$ reported that maltose was the best carbon and soy peptone was the best nitrogen sources for Fibrinolytic Enzyme (Nattokinase) production, however, Bhunia et al ${ }^{15}$ inferred that lactose gave the maximal activity. In our study, it was observed that maltose and soy peptone were the best carbon and nitrogen sources for optimal enzyme production and this result was in accordance with Liu et al. ${ }^{16}$.

In our experiemnt, the maximal activity obtained was at $200 \mathrm{rpm}$ in shake flask studies. Kumar and Takagi ${ }^{3}$ had tested different agitations $(0,50,100$ and $200 \mathrm{rpm})$ for the maximal production of fibrinolytic enzyme and according to them, the optimum agitation speed was $200 \mathrm{rpm}$, which gave the maximal activity. The ability of the Bacillus licheniformis isolate to produce fibrinolytic enzyme at different $\mathrm{pH}(6.2,6.8,7.2,7.5,8)$ was studied ${ }^{17}$. According to Siraj ${ }^{17}$, the productivity increased and the maximal activity was at the $\mathrm{pH}$ level of 7.2 , which corresponds with our results. We obtained the maximal activity on 72 $\mathrm{h}$, whereas, Ellaiah and Srinivasulu ${ }^{18}$ mentioned that the optimum incubation period for serine protease activity was $24 \mathrm{~h}$. However, Wang et al. ${ }^{7}$ mentioned that the maximal enzyme activity was achieved at $60 \mathrm{~h}$. The studies on the optimum $\mathrm{pH}$ and temperature on the enzyme activity revealed that the enzyme was active at a $\mathrm{pH}$ level of 7.07.5 and at temperatures of $45-50^{\circ} \mathrm{C}$. In a similar study, Babu et $\mathrm{al}^{19}$ observed that the optimum $\mathrm{pH}$ for enzyme activity was 7.0 and the temperature was $37^{\circ} \mathrm{C}$.

\subsection{Partial Purification of Fibrinolytic (Nattokinase) Enzyme}

The crude culture filtrate was purified partially with ammonium sulphate and acetone precipitation methods. In ammonium sulphate precipitation method, the fibrinolytic enzyme activity of B. amyloliquefaciens was 79.85 $\mathrm{FU} / \mathrm{mL}$ and $32.32 \mathrm{U} / \mathrm{mL}$ in acetone precipitation. In case of B. licheniformis, the fibrinolytic activity was $64.11 \mathrm{FU} /$ $\mathrm{mL}$ when precipitated with ammonium sulphate, while the activity was 24.21 in acetone precipitation. As regards the protein content, it was $21.0 \mathrm{mg} / \mathrm{mL}$ in crude enzyme preparation of B. amyloliquefaciens and $20.0 \mathrm{U} / \mathrm{mL}$ in $B$. licheniformis. In the ammonium sulphate precipitate, the protein content was $7.0 \mathrm{mg} / \mathrm{mL}$ ) in case of B. amyloliquefaciens and in B. licheniformis, it was $6.1 \mathrm{mg} / \mathrm{mL}$.

\subsection{Scale Up Studies}

Scale up trials in a $7 \mathrm{~L}$ Laboratory Fermentor were undertaken with $B$. amylolique-faciens. The minimal medium used earlier in our studies was used as the seed medium and the Maltose+WheatBran medium was used as the production medium. In the first batch, the maximal activity was only $24.9 \mathrm{FU} / \mathrm{mL}$ after $68 \mathrm{~h}$. In the second batch, after some fine-tuning of the fermentor, an activity of $42.6 \mathrm{FU} / \mathrm{mL}$ was achieved. In the third batch, a new seed medium containing soybean meal was tried. However, the activity was only $35.0 \mathrm{FU} / \mathrm{mL}$ after $70 \mathrm{~h}$. Therefore, the seed medium used for the first two batches was tried in the fourth batch with some modifications in the operating 
parameters of the fermentor. This batch, after $72 \mathrm{~h}$, yielded an activity of $55.6 \mathrm{FU} / \mathrm{mL}$ (compared to that of $28.98 \mathrm{mg} /$ $\mathrm{mL}$ in shake flask studies). The enzyme activity in the harvested broth after the filtration and centrifugation was $52 \mathrm{FU} / \mathrm{mL}$. When concentrated through Ultrafiltration, the activity increased to $210 \mathrm{FU} / \mathrm{mL}$. The concentrated enzyme was then made into a powder by Spray Drying Methods and the fibrinolytic activity in the powder was $745 \mathrm{FU} / \mathrm{g}$. The Fibrinolytic activity of the test enzyme was higher than the other commercial protease / fibrinolytic enzymes. The time taken by the test enzyme for dissolving the blood clot was nearly the same as that of other available fibrinolytic enzymes.

\subsection{Amplification of Serine Protease Gene}

Forward (5_-ATGGCGCAGTCCGTGCCTTAC-3_) and reverse (5_-TTACTG-AGCTGCCGCCTGTAC-3_) primers were designed from the nucleotide sequence corresponding to the Fibrinolytic Enzyme (Nattokinase) peptide $^{20}$ to amplify the sequence. Sequencing of the amplified fragment revealed $100 \%$ similarity between the peptides of the fibrinolytic (Nattokinase) from B. amyloliquefaciens and the published literature. Homology among these and other bacterial serine proteases was checked using the BLAST algorithm (NCBI, http:// www. ncbi.nlm.nih.gov). B. subtilis K-54, which originates from traditional Korean food, produces the fibrinolytic enzyme subtilisin K-54. The fibrinolytic (Nattokinase) enzyme produced by our strain, B. amyloliquefaciens, isolated from spoilt milk and subtilisin K-54 displayed the highest similarity and may therefore have a very similar threedimensional structure, especially around the substrate binding sites ${ }^{21}$.

\subsection{Protein Structure Prediction}

The crystal structure is unavailable for serine protease so the similarity between 1SNB_E and serine protease shows that 1SBN_E can be used as template sequence for 3-Dimensional structure modelling of target protein.

\section{Conclusion}

In this research work, two species of Bacillus, namely, Bacillus amyloliquefaciens and Bacillus licheniformis, were isolated from spoilt milk and soy flour, respectively, which exhibited fibrinolytic (Nattokinase) activity. In the laboratory scale studies, of these two cultures,
B. amyloliquefaciens produced the Fibrinolytic enzyme in higher quantities, $28.98 \mathrm{FU} / \mathrm{mL}$, compared to 26.63 $\mathrm{FU} / \mathrm{mL}$ in $B$. licheniformis. The maximal activities were obtained after $72 \mathrm{~h}$. The optimum conditions at laboratory for maximal production of the fibrinolytic (Nattokinase) enzyme were: $\mathrm{pH} 7.2$, temperature $37 \mathrm{C}$ and agitation 200 $\mathrm{rpm}$. When scale up studies with $B$. amyloliquefaciens in a laboratory $7 \mathrm{~L}$ Fermentor were undertaken, the maximal activity obtained $55.6 \mathrm{FU} / \mathrm{mL}$ in $72 \mathrm{~h}$, compared to that of $28.98 \mathrm{FU} / \mathrm{mL}$ in shake flask studies. The increase in activity in the Fermentor by about 2 times more than the shake flasks clearly indicates that the activity of $55.6 \mathrm{FU} /$ $\mathrm{mL}$ is positively expected to increase to about $100.0 \mathrm{FU} /$ $\mathrm{mL}$ in the large fermentors during commercial operation. After Ultrafiltration, the activity improved to $210 \mathrm{FU} / \mathrm{mL}$ and in the spray dried powder, the activity as $745 \mathrm{FU} / \mathrm{g}$. The molecular weight of the enzyme was estimated to be about $38 \mathrm{kDa}$. The enzyme had exhibited excellent blood clot dissolving property and therefore may be considered for further scale up and commercial exploitation.

Now that the growth conditions as well as the operating parameters are optimised for the production of Fibrinolytic Enzyme (Nattokinase) in the laboratory scale, it would be taken up for large scale production and ultimately commercial application. Based on the scale up studies in a $7 \mathrm{~L}$ fermentor, it was proven that soybean meal and peptone are the most effective substrates for the production of this Fibrinolytic enzyme. This serine protease enzyme has a good stability at high $\mathrm{pH}$ levels and broad heat stability thereby permitting its wide biotechnological potentials. Moreover, this enzyme shows a high degree of specificity towards fibrin, as evidenced in our study, and thus promises to be useful in thrombolytic therapy. It would, naturally provide an alternative to the otherwise costly enzymes that are currently used in treating cardiovascular diseases, as large quantities of this enzyme can be conveniently produced at a much lesser cost. The future prospects of this study are to scale up the production trials in fermentors of $50 \mathrm{~L}$ and above capacities. The downstream processing has to be standardized in order to reduce the loss in activity and to formulate the enzyme as a powder for commercial exploitation as a Nutraceutical.

\section{Acknowledgement}

Rajani Gopal Gad thanks SRM University for their support and encouragement towards her doctoral research work. The authors thank SynkroMax Biotech Pvt Ltd, 
Chennai, for their continuous support and proving facilities for carrying out application and scale up trials.

\section{References}

1. Wanda L, Rivera-Bou WL. Thrombolytic Therapy. Medscape e-Journal. 2014.

2. Anonymous. Thrombolytic agents. MedicineNet.com. 2014.

3. Kumar G, Takagi H. Microbial alkaline proteases: From a bioindustrial viewpoint. Biotechnol Adv. 1999; 17:561-94.

4. Sumi H, Hamada H, Tsushima H, Mihara H, Muraki H. A novel Fibrinolytic enzyme (Nattokinase) in the vegetable cheese Natto; a typical and popular soybean food in the Japanese diet. Experientia. 1987; 15:1110-1.

5. Coolbear T, Eames CV, Casey Y, Daniel RM, Morgan HW. Screening of strains identified as extremely thermophilic bacilli for extracellular proteolytic actinvitee and general property of proteinases from two of the strains. J Appl Bacteriol. 1991; 71:252.

6. Deepak V, Kalishwarlal K, Ramakumarpandian S, Babu VS, Senthilkumar SR, Sangailiyandi G. Optimisation of media composition for Nattokinase production by Bacillus subtilis using Response Surface Methodology. Bioresource Tech. 2008; 99:8170-4.

7. Wang S, Chen H, Liang T, Lin Y. A novel Nattokinase produced by Pseudomonas sp., TKU015 using shrimp shells as substrate. Process Biochem. 2009; 44:70-6.

8. Bednarski A. Identifying unknown bacteria using biochemical and molecular methods. Washing University at St Louis. 2006; 2-6.

9. Bradford M. A rapid and sensitive method for the quantization of microgram quantities of protein using the principles of protein-dye binding. Anal Biochem. 1976; 72:248-54.

10. Sambrook J, Frisch EF, Maniatis T. Molecular Cloning. Cold Spring Harbour Laboratories, New York: 1989.

11. Saito H, Miura K. Preparation of transforming deoxyribonucleic acid by phenol treatment. Biochem Biophys Act. 1963; 72:619-29.

12. Duguid JP. Genus Bacillus. In: College JG, Fraser AG, Marmion BP and Simmons A, editors. Mackie and McCartney Practical Medical Microbiology. New York: Churchill Livingstone; 1996. p. 317-27.
13. Sneath PHA, Mair NS, Sharp ME, Holt JG. Bergeys Manual of Systematic Bacteriology. USA: Williams and Wilkins; 1986. p. 1105-38.

14. Al-Jumaily EF, Daweed AW, Nadir MI. Production of alkaline protease from local Bacillus stearothermophilus AEAL2 by solid state fermentation. Iraqi J Biotech. 2004; 3:137-55.

15. Bhunia B, Dutta D, Chaudhuri S. Selection of Suitable Carbon, Nitrogen and Sulphate Source for the Production of Alkaline Protease by Bacillus licheniformis NCIM-2042. Not Sci Biol. 2010; 2:56-9.

16. Liu J, Xing J, Chang T, Ma Z, Liu H. Optimization of nutritional conditions for Nattokinase production by Bacillus natto NLSSE using statistical experimental methods. Process Biochem. 2005; 40:2757-62.

17. Siraj SG. Comparative studies on production of Nattokinase from Bacillus subtilis changing the nitrogen sources [MA Thesis]. Rajiv Gandhi University of Health Sciences, Karnataka; 2011.

18. Ellaiah P, Srinivasulu B. Production of extracellular protease by Streptomyces fradiae. Hindustan Antibiot Bull. 1996; 38:41-7.

19. Babu N, Amirtham D, Ramachandran R, Purnima. Morphological, biochemical and molecular characterisation of a non-chitinase protease producing bacteria, its biodegrading effect on shell fish waste and its enzyme kinetics. Elixir Biotech. 2013; 55:13116-9.

20. Vasantha N, Thompson LD, Rhodes C, Banner CDB, Nagle J, Filpula D. Genes for alkaline protease and neutral protease from Bacillus amyloliquefaciens contain a large open reading frame between the regions coding for signal sequence and mature protein. J Bacteriol. 1984; 159:811-9.

21. Peng Y, Yang X, Xiao L, Zhang Y. Cloning and expression of a fibrinolytic enzyme (subtilisin DFE) gene from Bacillus amyloliquefaciens DC-4 in Bacillus subtilis. Res Microbiol. 2004; 155:167-73.

22. Jun-Guo Liu, Jian-Min Xing, Rui Shen, Cheng- li Yang, Hui-Zhon Liu. Reverse Miscelles extraction of Nattokinase from fermentation broth. Biochemical Engineering Journal. 2004; 21:273-8.

23. Wang C, Du M, Zheng D, Kong F, Zu G, Feng Y. Purification and Characterization of Nattokinase from Bacillus subtilis natto B-12. J Agri Food Chem. 2009; 57:9722-9. 